\title{
MEDICO-BIOLOGICAL JUSTIFICATION \\ OF MULTIDISCIPLINARY PHYSICAL THERAPY PROGRAMS \\ FOR THE DISEASES' PREVENTION \\ OF UKRAINIAN SCHOOL-AGE CHILDREN
}

\section{Pyurko V. E., Kazakova S. M.}

\section{INTRODUCTION}

Topic relevance. In recent decades, new negative trends in the formation of public health have persisted and are emerging in Ukraine. The most important of them is the deterioration of physical development and health of children and adolescents, which in the near future form the labor, defense, intellectual and reproductive potential of society ${ }^{1}$. According to official statistics, the overall incidence of children in Ukraine over the past 5 years has increased by $16 \%$, adolescents-by $18 \%$. The primary incidence of children in Ukraine has increased by $12 \%$ in recent years, and adolescents by $35 \%{ }^{2}$. There is deterioration in physical development indicators and an increase in deceleration processes. The frequency of low body weight in children and its deficit is 3 times more frequent than 10 years $\mathrm{ago}^{3}$.

According to the law of Ukraine "On education" (2014), a school should be a place that ensures not only the preservation, but also the strengthening of students' health. Therefore, one of the national priorities at present is to strengthen the physical and mental health of schoolchildren. However, numerous studies have shown that adverse changes in adolescent health are most pronounced during school ${ }^{4}$. By the end of the school year, children intensively manifest functional disorders of the Central nervous system, physical development indicators deteriorate, General morbidity increases, chronic diseases worsen, adaptive capabilities and reserves of the body are reduced. While the overall incidence among children aged $0-14$ years and adults has increased by $8.4 \%$ and $7.5 \%$, respectively, over the past decade, the overall incidence among adolescents aged 15-18 years has increased by $38.1 \%$. During the period of schooling, the number of healthy children

\footnotetext{
${ }^{1}$ Григорьев К.И. Адаптация и стресс в детском возрасте. Москва : МЕДпресс-информ, 2014. 304 с.

${ }^{2}$ Мухін В.М. Фізична реабілітація. Київ : Олімпійська література, 2005. 472 с.

${ }^{3}$ Barkmann C. Applicability and efficacy of variable light in school. Physiology \& Behavior. 2012. Vol. 105. P. 621-627.

4 Галактионова М.Ю. Синдром вегетативной дисфункции у детей и подростков: вопросы диагностики, лечения, диспансеризации : методические рекомендации. Москва : МЕДпресс-информ, 2015. $48 \mathrm{c}$.
} 
decreases by $4-5$ times, and only $2-5 \%$ of teenagers graduate from school practically healthy ${ }^{5}$.

Along with the reasons of socio-economic nature, scientists emphasize that the health and physical development of children is negatively affected by environmental factors, serious deficiencies in nutrition, unfavorable conditions of education and training that do not comply with hygiene standards and sanitary rules, including the intensification of the educational process, the spread of bad habits. An alarming situation has developed with the spread of alcohol abuse, Smoking, and drug use among children and adolescents.

In modern conditions is the modernization of school education, introducing state standards of the second generation, evolving a learner-centered approach to teaching students, changing the system of admission of students-students in universities ${ }^{6}$. Modern school is characterized by the variability of the educational process aimed at improving the level of basic school knowledge, the formation of professional orientation and motivation for a conscious choice of future profession, and further adaptation to the conditions of study at the University. Educational innovations in schools are implemented against the background of negative indicators of adolescent health. The deterioration of physical development and the growth of morbidity in children and adolescents in the framework of innovative educational processes determine the relevance of studying the factors that affect these indicators, and the development of preventive measures to reduce their negative impact on the younger generation.

In the literature, there are few and contradictory data on the health status of students of specialized, including medico-biological, classes and it's forming factors ${ }^{7}$. The lack of scientific information about the organization of the educational process, lifestyle, modes and diets of schoolchildren of medical and biological classes in modern conditions has become the basis for studying the impact of these factors on physical development, health status of high school students and developing recommendations based on health saving effect.

The research object is the process of forming a healthy lifestyle of high school students in modern Ukrainian schools under the influence of physical therapy methods.

\footnotetext{
${ }^{5}$ Гольдштейн Н.И., Гольдштейн Р.Н. Свежий воздух, супероксид и здоровье. Наука и жизнь. 2009. № 1. С. 94-99.

6 Лильин Е.Т., Доскин В.А. Детская реабилитология. Москва : Литература, 2011. 609 с.

Мухін В.М. Фізична реабілітація. Київ : Олімпійська література, 2005. 472 с.

Мухін В.М., Мальованій А.В., Мальована Г.П. Основи фізичної реабілітації. Львів, 2009. 120 с.

Barkmann C. Applicability and efficacy of variable light in school. Physiology \& Behavior. 2012. Vol. 105. P. 621-627.

7 Лильин Е.Т., Доскин В.А. Детская реабилитология. Москва : Литература, 2011. 609 с.

Мухін В.М. Фізична реабілітація. Київ : Олімпійська література, 2005. 472 с.

Мухін В.М., Мальованій А.В., Мальована Г.П. Основи фізичної реабілітації. Львів, 2009. 120 с.
} 
The research subject is the prediction of physical health and adaptation of Ukrainian schoolchildren who study in general education and medical and biological classes of senior level under the influence of physical therapy methods.

The research aim is to provide scientific justification for methods of physical therapy in the prevention of health disorders in school children based on a comparative study of educational conditions in biomedical and general education classes.

\section{Materials and methods}

In the course of theoretical study of the problem, experimental research and experimental work, theoretical analysis and generalization of scientific and methodological literature on physical therapy, human physiology and anatomy, materials of periodicals were used. In total, 80 students took part in the experiment: 40 boys and 40 girls. For high school students of medical and biological classes, additional physical therapy classes were introduced to the class schedule, where they engaged in therapeutic gymnastics, outdoor games, and the like. The organization and content of the study are shown in Fig. 1 and table 1 . A research program is shown in figure 2.

Table 1

Main research directions and methods

\begin{tabular}{|c|l|}
\hline $\begin{array}{c}\text { Study of the learning } \\
\text { process }\end{array}$ & $\begin{array}{l}- \text { weekly load volume, } \\
- \text { evaluation of the training schedule, } \\
- \text { computer classes }\end{array}$ \\
\hline $\begin{array}{c}\text { Studying the nutrition } \\
\text { of high school children }\end{array}$ & $\begin{array}{l}\text { - diet, } \\
\text { - qualitative characteristics of food } \\
\text { (according to the survey data), }\end{array}$ \\
\hline $\begin{array}{c}\text { Research on the way of } \\
\text { life of schoolchildren }\end{array}$ & $\begin{array}{l}- \text { motor activity, } \\
- \text { leisure, }\end{array}$ \\
\hline $\begin{array}{c}\text { Evaluation of physical } \\
\text { development }\end{array}$ & $\begin{array}{l}\text { - anthropometric indicators, } \\
- \text { vital capacity of the lungs (VCL), }\end{array}$ \\
\hline $\begin{array}{c}\text { Studying the health } \\
\text { status of schoolchildren }\end{array}$ & $\begin{array}{l}- \text { subjective assessment of health, } \\
- \text { medical examination data, }\end{array}$ \\
\hline $\begin{array}{c}\text { Mathematical and } \\
\text { statistical data } \\
\text { processing }\end{array}$ & $\begin{array}{l}\text { - psychophysiological questionnaire, } \\
- \text { Statistica 6.0 program, }\end{array}$ \\
\hline
\end{tabular}


Statistical analysis of the obtained data was performed using computer programs Statistic 6.0 and Microsoft Excel. These programs allow comparison of the studied data groups using parametric and nonparametric criteria (student's t-test and Spearman's test). The programs used automatically compare groups of data obtained by a given attribute, revealing the reliability of differences between groups with the level of significance of differences: $p \leq 0,05 ; p \leq 0,01 ; p \leq 0,001^{8}$.

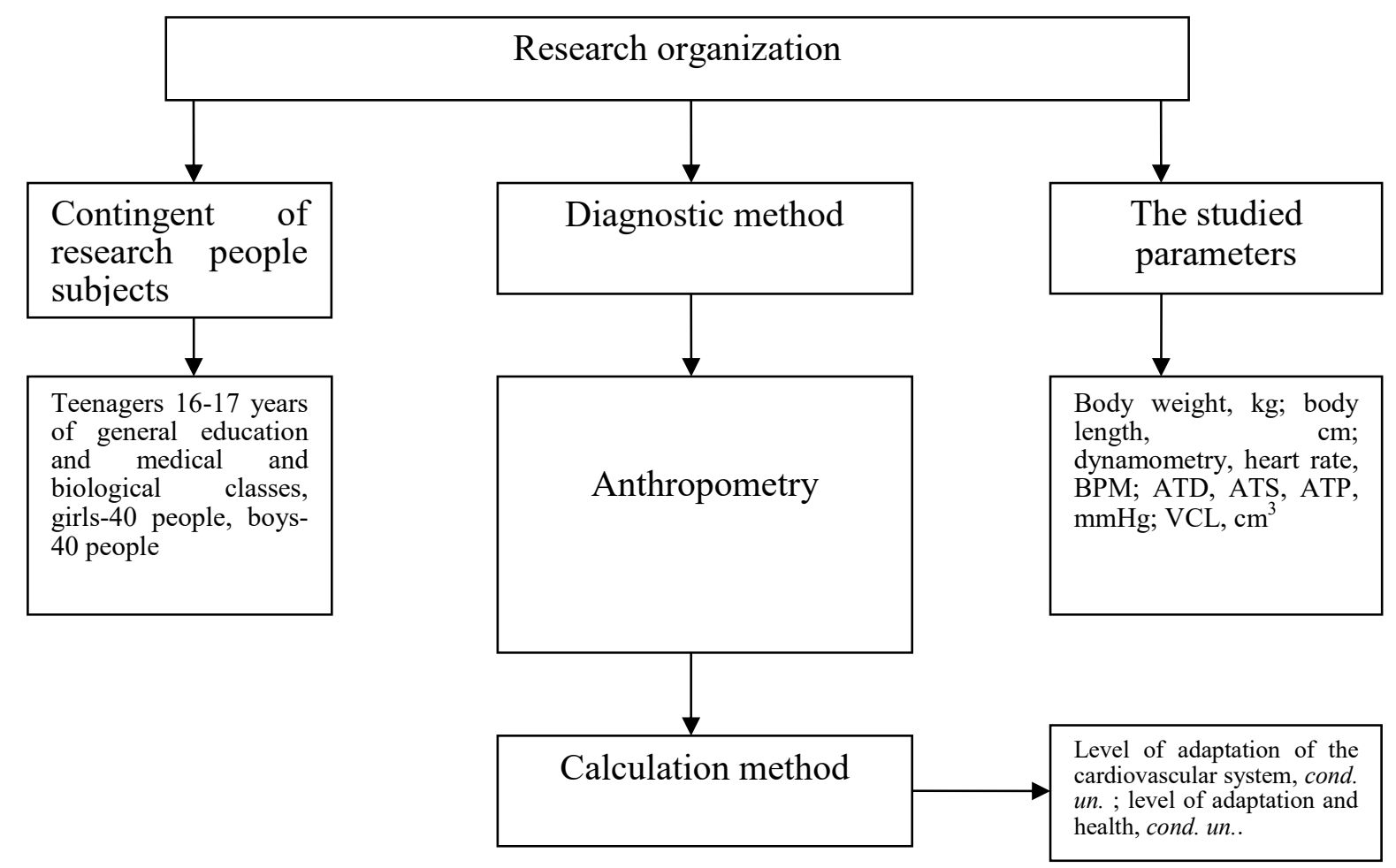

Fig. 1. Diagram of the research organization

\footnotetext{
8 Галактионова М.Ю. Синдром вегетативной дисфункции у детей и подростков: вопросы диагностики, лечения, диспансеризации : методические рекомендации. Москва : МЕДпресс-информ, 2015. $48 \mathrm{c}$.

Гольдштейн Н.И., Гольдштейн Р.Н. Свежий воздух, супероксид и здоровье. Наука и жизнь. 2009. № 1. С. 94-99.

Григорьев К.И. Адаптация и стресс в детском возрасте. Москва : МЕДпресс-информ, 2014. 304 с.

Лильин Е.Т., Доскин В.А. Детская реабилитология. Москва : Литература, 2011. 609 с.

Мухін В.М. Фізична реабілітація. Київ : Олімпійська література, 2005. 472 с.

Мухін В.М., Мальованій А.В., Мальована Г.П. Основи фізичної реабілітації. Львів, 2009. 120 с.

Barkmann C. Applicability and efficacy of variable light in school. Physiology \& Behavior. 2012. Vol. 105. P. 621-627.

Boreham C., Riddoch C. The physical activity, fitness and health of children. J. Sport Sci. 2011. Vol. 19. P. 915-929.

Grigg J. Air pollution and children's respiratory health - gaps in the global evidence. Clin Exp Allergy. 2011. Vol. 41 (8). P. 1072-1075.
} 


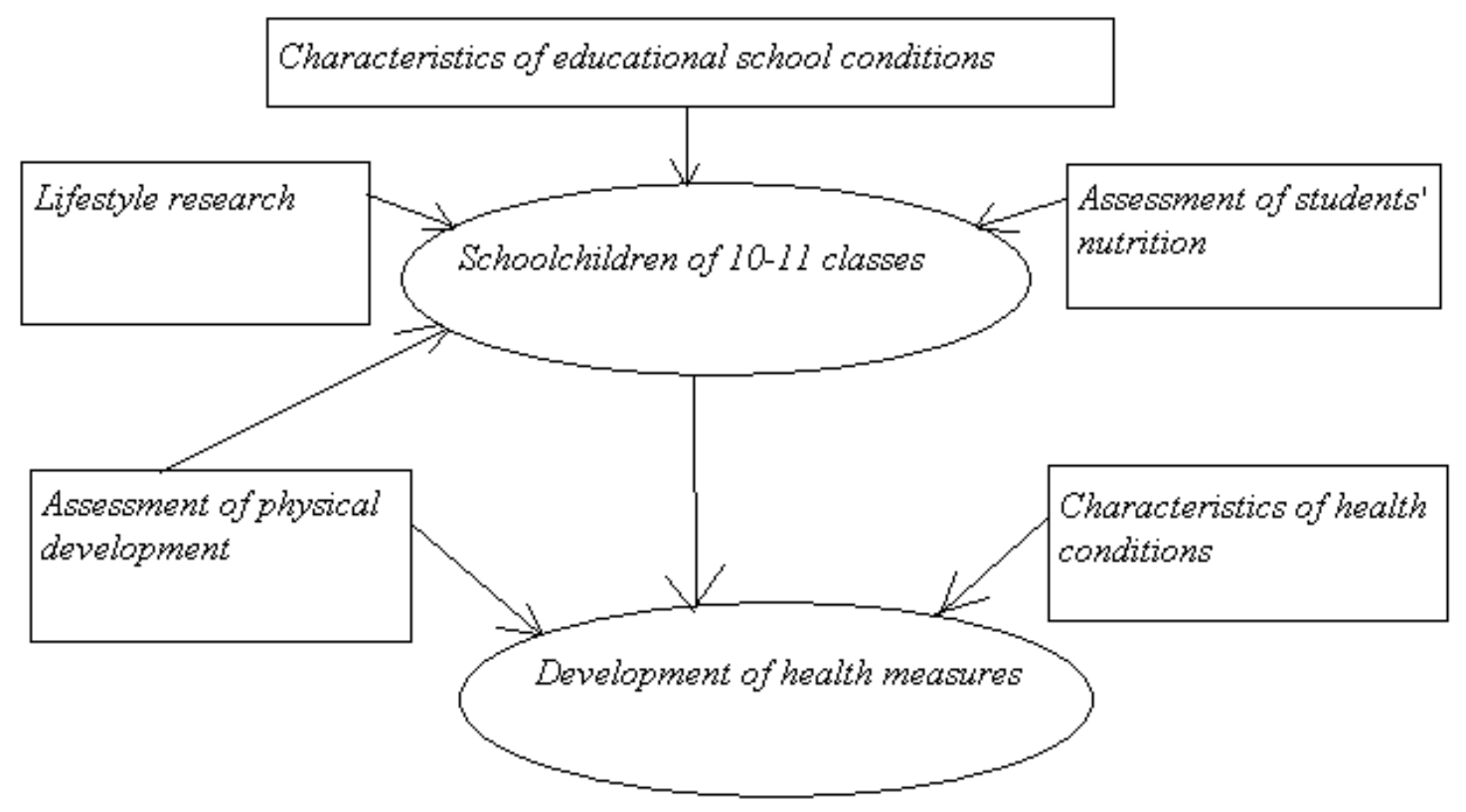

\section{Fig. 2. Program for studying the conditions of training for physical development and health of high school children}

\section{Research result}

The problem of hypodynamia is relevant for people engaged in mental activity, among which it is necessary to distinguish students of secondary and higher schools. Limited motor activity negatively affects the structure and functions of all tissues of the body, leads to a decrease in protective forces and increases the possibility of functional disorders and the formation of pathology ${ }^{9}$ [8]. About $40 \%$ of girls and $73,5-74,0 \%$ of boys regularly do physical education at school (almost 2 times more). At the same time, $11-12 \%$ of girls do not attend physical education classes, which is 3 times more than boys. In their spare time, $48-52 \%$ of boys plays sports, while $78-80 \%$ of girls, on the contrary, do not engage in any motor activity outside of school. When assessing the intensity of sports, it is shown that half of the guys go to the sports section from 2 to 6 times a week, which may indicate a large motor load. A small proportion of girls (6-7\%) only occasionally attend sports or dance classes, which confirms the lack of physical exercise in high school girls. So, it is established that high school students should move due to a large educational load, and hypodynamia is more typical for girls (40\%) than for boys $(74 \%)$.

Modern society is characterized by the introduction of computer technology and information technology in all spheres of human life and

\footnotetext{
${ }^{9}$ Grigg J. Air pollution and children's respiratory health - gaps in the global evidence. Clin Exp Allergy. 2011. Vol. 41 (8). P. 1072-1075.
} 
activity, including the educational process, which has led to an increase in the number of students who use computers. It was found that $100 \%$ of the surveyed students have a computer at home and can work on it. Only $2.2 \%$ of boys in General education classes do not know how to do this. More than $70 \%$ of school children learned and started working on it from the age of $8-11$. At the same time, more than $50 \%$ of students spend $1-3$ hours at the computer for a day, and $23-25 \%$ of high school students - from 3 to 5 hours per day at the recommended rate of 30-60 minutes per day.

Research has shown that $65-80 \%$ of schoolchildren are informed about the harmful effects of working on the computer on their health, despite this, more than half are not ready to give up using it in the process of preparing tasks and teaching at school. It was found that long-term work at the computer, in the opinion of respondents, does not cause significant differences in the wellbeing of students of medical and biological and general education classes. Fatigue is observed in $21,7-22,7 \%$ of school children, back pain-in $15.8 \%$ $16.2 \%$ of girls, and pain in the eyes-13,5-14,2\% of students of both types of schools. At the same time, half of school children (49.3-58.9\%) do not experience any unpleasant feelings in their own well-being. However, there is a difference in the reaction of girls and boys. Thus, significantly more girls experience pain in their back and hands, and girls of medical and biological classes also have headaches.

The main activities of children with a computer are games, reference and information. It can be noted that the majority of schoolchildren $(70,3-79,0 \%)$ receive the necessary information from the Internet. $43,8-56,8 \%$ of respondents receive various information from mass media (Newspapers, magazines, television), and 33,8 - 38,9\% of students of both types of classes receive information from parents. A third of students in medical and biological classes $(34,2 \%$ of girls and $35,8 \%$ of boys) receive the necessary information (knowledge) from teachers in the classroom, which is 1,3 times more than students in general education classes. It is proved that in General education classes only $5,9 \%$ of girls get knowledge in school. It is important to note that school textbooks read and extract useful information from them significantly more girls $(27,2 \%$ against $5,9 \% ; p \leq 0,001)$ and boys $(30,9 \%$ against $20,5 \% ; p \leq 0,05)$ in medical and biological classes. In the day mode of high school students, in addition to school classes, sleep and homework preparation, free time is of great importance (table 2). It is determined that there are certain differences in the organization of leisure for schoolchildren in specialized classes compared to general education classes.

Thus, girls of medical and biological classes $(52,6 \%)$ significantly read more books at leisure. Significantly more girls and boys of specialized classes $(30,5$ and $32,1 \%$ against 15,7 and $14,1 \% ; \mathrm{p} \leq 0.01)$ are engaged with Tutors, attend educational circles. About $30 \%$ of all students watch TV in their free time $(24,0-29,7 \%)$, and about $70 \%$ of all students communicate with friends, 
regardless of their profile. It is interesting to note that compared to boys, significantly more girls read books at leisure, visit theaters, museums and exhibitions. In turn, compared to girls, significantly more boys spend time with computers and attend sports clubs.

Table 2

Research of leisure time of school children according to the survey data

\begin{tabular}{|l|c|c|c|c|}
\hline \multirow{2}{*}{$\begin{array}{c}\text { In your free time you } \\
\text { prefer: }\end{array}$} & \multicolumn{2}{|c|}{ Medical and biological classes } & \multicolumn{2}{c|}{ General education classes } \\
\cline { 2 - 5 } & girls, \% & guys, \% & girls, \% & guys, \% \\
\hline read books & $\begin{array}{c}52,6^{*} \\
(\mathrm{p} \leq 0,05)\end{array}$ & $\begin{array}{c}26,9^{*} \\
(\mathrm{p} \leq 0,05)\end{array}$ & $\begin{array}{c}40,2^{*} \\
(\mathrm{p} \leq 0,05)\end{array}$ & 27,6 \\
\hline watch TV & 25,4 & 29,6 & 24,0 & 29,7 \\
\hline $\begin{array}{l}\text { attend sports clubs, } \\
\text { dance schools }\end{array}$ & 13,6 & $\begin{array}{c}30,2^{*} \\
(\mathrm{p} \leq 0,01)\end{array}$ & 14,2 & $\begin{array}{c}30,3^{*} \\
(\mathrm{p} \leq 0,05)\end{array}$ \\
\hline $\begin{array}{l}\text { visit theaters, } \\
\text { museums, exhibitions }\end{array}$ & $\begin{array}{c}24,6^{*} \\
(\mathrm{p} \leq 0,05)\end{array}$ & 14,2 & $\begin{array}{c}24,0^{*} \\
(\mathrm{p} \leq 0,05)\end{array}$ & 13,5 \\
\hline attend electives, clubs & 13,6 & 10,5 & 9,8 & 9,2 \\
\hline $\begin{array}{l}\text { attend educational } \\
\text { courses, classes with } \\
\text { a tutor }\end{array}$ & $\begin{array}{c}30,5^{*} \\
(\mathrm{p} \leq 0,01)\end{array}$ & $\begin{array}{c}32,1^{*} \\
(\mathrm{p} \leq 0,01)\end{array}$ & 15,7 & 14,1 \\
\hline $\begin{array}{l}\text { communicate with } \\
\text { friends }\end{array}$ & 78,7 & 64,8 & 76,0 & 63,8 \\
\hline $\begin{array}{l}\text { "communicate" with } \\
\text { a computer }\end{array}$ & 43,4 & $\begin{array}{c}64,2^{*} \\
(\mathrm{p} \leq 0,01)\end{array}$ & 44,1 & $\begin{array}{c}63,8^{*} \\
(\mathrm{p} \leq 0,01)\end{array}$ \\
\hline other & 13,2 & 12,3 & 14,2 & 13,5 \\
\hline
\end{tabular}

* An asterisk indicates the validity of differences between boys and girls

Physical development is a dynamic process of growth, that is, changes in the complex of morphofunctional characteristics of the body, which include appearance, body size, body type, increase in muscle mass and strength, and biological maturity. Assessment of physical development of schoolchildren was carried out using regression scales. It is determined that the proportion of boys and girls with harmonious physical development in General education and medical and biological classes does not have significant differences and is more than half of the surveyed high schoolchildren. However, girls $(22,5 \%)$ of general education classes are overweight, which significantly differs from the corresponding indicator for girls studying in medical and biological classes. It is important to note the downward trend in the proportion of high school students with a body mass deficit (almost 1,5 times), as well as an increase in the proportion of students with low growth (boys 5 times, girls 2 times) in specialized classes.

Also, a self-assessment questionnaire was conducted among students of medical and biological and general education classes. The questionnaire included questions about the state of health, pain in the limbs, gastrointestinal tract, nervousness, irritability, and so on. According to the survey, $36,0 \%$ of 
girls and $59,9 \%$ of boys in medical and biological classes feel absolutely healthy, which does not differ from similar data in General education classes. $54,8 \%$ of girls and $56,9 \%$ of boys in medical and biological classes feel almost healthy, while about $10 \%$ of schoolchildren feel unhealthy. A more detailed survey of schoolchildren about their health revealed some features of their condition. For example, $60-79 \%$ of school children almost never feel headache, dizziness and stomach pain, $54-60 \%$ of school children - pain in the extremities. At the same time, the girls were the most sensitive group, in which headache was distinguished almost every week, monthly - pain in the stomach and extremities.

The state of the nervous system, according to respondents, was tense. In $20 \%$ of girls and $10 \%$ of boys in medical and biological classes, a bad mood was indicated every day, in more than $20 \%$ of students- 1 time a week or 1 time a month. Only $15-30 \%$ of school children almost never had a bad mood. Bad mood of schoolchildren, as a rule, was accompanied by irritability and nervousness, which were manifested almost constantly. This led to a violation of falling asleep and deep restful sleep in $50 \%$ of schoolchildren (table 3 ). The study of the health of children and adolescents, the distribution of health groups is an important criterion for the comparative analysis of the health of children and adolescents in various conditions (climate and territorial features, features of education, upbringing, etc.), as well as to identify risk factors for their health.

Table 3

Assessment of well-being according to a survey conducted among students of medical-biological and general education classes

\begin{tabular}{|c|c|c|c|c|}
\hline \multirow{2}{*}{$\begin{array}{l}\text { How often have You been } \\
\text { feeling lately }\end{array}$} & \multicolumn{2}{|c|}{$\begin{array}{c}\text { Medical and biological } \\
\text { classes }\end{array}$} & \multicolumn{2}{|c|}{ General education classes } \\
\hline & girls, $\%$ & guys, $\%$ & girls, $\%$ & guys, $\%$ \\
\hline 1 & 2 & 3 & 4 & 5 \\
\hline \multicolumn{5}{|c|}{ Headache } \\
\hline almost every day & 8,5 & 5,6 & 11,8 & 7,0 \\
\hline more than 1 time per week & 6,6 & 1,2 & 5,4 & 0 \\
\hline almost every week & $\begin{array}{c}9,5^{*} \\
(p \leq 0,05)\end{array}$ & 3,7 & $\begin{array}{c}12,2^{*} \\
(\mathrm{p} \leq 0,01)\end{array}$ & 4,3 \\
\hline almost every month & 14,7 & 10,5 & 15,7 & 11,4 \\
\hline almost never & 60,7 & 79,0 & 54,9 & 77,3 \\
\hline \multicolumn{5}{|c|}{ Stomach ache } \\
\hline almost every day & 1,8 & 0 & 2,0 & 0 \\
\hline more than 1 time per week & 0 & 6,2 & 0,5 & 4,9 \\
\hline almost every week & 5,9 & 2,5 & 5,9 & 2,2 \\
\hline almost every month & $\begin{array}{c}27,6^{*} \\
(p \leq 0,001)\end{array}$ & 16,0 & $\begin{array}{c}28,4^{*} \\
(\mathrm{p} \leq 0,001)\end{array}$ & 16,2 \\
\hline almost never & 64,7 & 75,3 & 63,2 & 76,7 \\
\hline \multicolumn{5}{|c|}{ Pain in legs } \\
\hline almost every day & 4,4 & 14,2 & 5,9 & 13,5 \\
\hline
\end{tabular}


Table 3 (Continued)

\begin{tabular}{|c|c|c|c|c|}
\hline 1 & 2 & 3 & 4 & 5 \\
\hline more than 1 time per week & 12,5 & 6,8 & 6,9 & 6,5 \\
\hline almost every week & 7,3 & 7,4 & 8,3 & 6,5 \\
\hline almost every month & $\begin{array}{c}21,0^{*} \\
(\mathrm{p} \leq 0,001)\end{array}$ & 12,3 & $\begin{array}{c}22,0^{*} \\
(\mathrm{p} \leq 0,001)\end{array}$ & 13,5 \\
\hline almost never & 54,8 & 59,3 & 56,9 & 60,0 \\
\hline \multicolumn{5}{|c|}{ Bad mood } \\
\hline almost every day & $\begin{array}{c}22,8^{*} \\
(\mathrm{p} \leq 0,01)\end{array}$ & 10,5 & $\begin{array}{c}24,5^{*} \\
(\mathrm{p} \leq 0,01)\end{array}$ & 11,9 \\
\hline more than 1 time per week & 19,5 & 12,3 & 20,6 & 13,0 \\
\hline almost every week & 23,9 & 23,5 & 23,0 & 23,2 \\
\hline almost every month & 13,2 & $\begin{array}{c}22,2^{*} \\
(\mathrm{p} \leq 0,01)\end{array}$ & 16,2 & $\begin{array}{c}23,8^{*} \\
(\mathrm{p} \leq 0,01)\end{array}$ \\
\hline almost never & 20,6 & 31,5 & 15,7 & 28,1 \\
\hline \multicolumn{5}{|c|}{ Irritability } \\
\hline almost every day & $\begin{array}{c}18,8^{*} \\
(\mathrm{p} \leq 0,001)\end{array}$ & 3,7 & $\begin{array}{c}23,5^{*} \\
(\mathrm{p} \leq 0,001)\end{array}$ & 4,3 \\
\hline more than 1 time per week & 19,8 & 21,6 & 20,6 & 22,2 \\
\hline almost every week & 21,3 & 24,1 & 22,1 & 24,3 \\
\hline almost every month & 9,9 & $\begin{array}{c}20,4^{*} \\
(\mathrm{p} \leq 0,01)\end{array}$ & 9,8 & $\begin{array}{c}21,1^{*} \\
(\mathrm{p} \leq 0,01)\end{array}$ \\
\hline almost never & 30,2 & 30,2 & 24,0 & 28,1 \\
\hline \multicolumn{5}{|c|}{ Nervousness } \\
\hline almost every day & $\begin{array}{c}18,7^{*} \\
(\mathrm{p} \leq 0,001)\end{array}$ & 3,7 & $\begin{array}{c}20,1^{*} \\
(\mathrm{p} \leq 0,001)\end{array}$ & 4,3 \\
\hline more than 1 time per week & 19,5 & 10,5 & 19,6 & 11,4 \\
\hline almost every week & 21,7 & 17,3 & 22,1 & 17,8 \\
\hline almost every month & 10,3 & $\begin{array}{c}20,4 \\
(p \leq 0,05)\end{array}$ & 10,3 & $\begin{array}{c}20,0^{*} \\
(\mathrm{p} \leq 0,05)\end{array}$ \\
\hline almost never & 29,8 & $\begin{array}{c}48,1^{*} \\
(\mathrm{p} \leq 0,01)\end{array}$ & 27,9 & $\begin{array}{c}46,5^{*} \\
(\mathrm{p} \leq 0,01)\end{array}$ \\
\hline \multicolumn{5}{|c|}{ Difficulty falling asleep } \\
\hline almost every day & 9,9 & 6,2 & $\begin{array}{c}16,2^{*} \\
(p \leq 0,01)\end{array}$ & 7,0 \\
\hline more than 1 time per week & 4,0 & 4,3 & 3,9 & 5,4 \\
\hline almost every week & 14,0 & 15,4 & 12,2 & 15,7 \\
\hline almost every month & 18,8 & 20,4 & 15,7 & 20,0 \\
\hline almost never & 53,3 & 53,7 & 52,0 & 51,9 \\
\hline \multicolumn{5}{|c|}{ Dizziness } \\
\hline almost every day & 2,9 & 3,7 & 3,9 & 4,3 \\
\hline more than 1 time per week & $\begin{array}{c}6,3^{*} \\
(\mathrm{p} \leq 0,001)\end{array}$ & 0,6 & $\begin{array}{c}7,8^{*} \\
(\mathrm{p} \leq 0,05)\end{array}$ & 2,2 \\
\hline almost every week & 5,5 & 0 & $\begin{array}{c}5,9^{*} \\
(\mathrm{p} \leq 0,05)\end{array}$ & 0,5 \\
\hline almost every month & 8,8 & 9,9 & 9,8 & 11,4 \\
\hline almost never & 76,5 & 85,8 & 72,6 & 81,6 \\
\hline
\end{tabular}

Note* indicates the validity of differences between boys and girls 
The results of the medical examination of students in grades 10-11 ( 40 boys and 40 girls, and the health group were determined) were analyzed. According to the data obtained, the distribution of health groups among students of general education and specialized classes does not differ significantly from each other (Fig. 3 and Fig. 4).

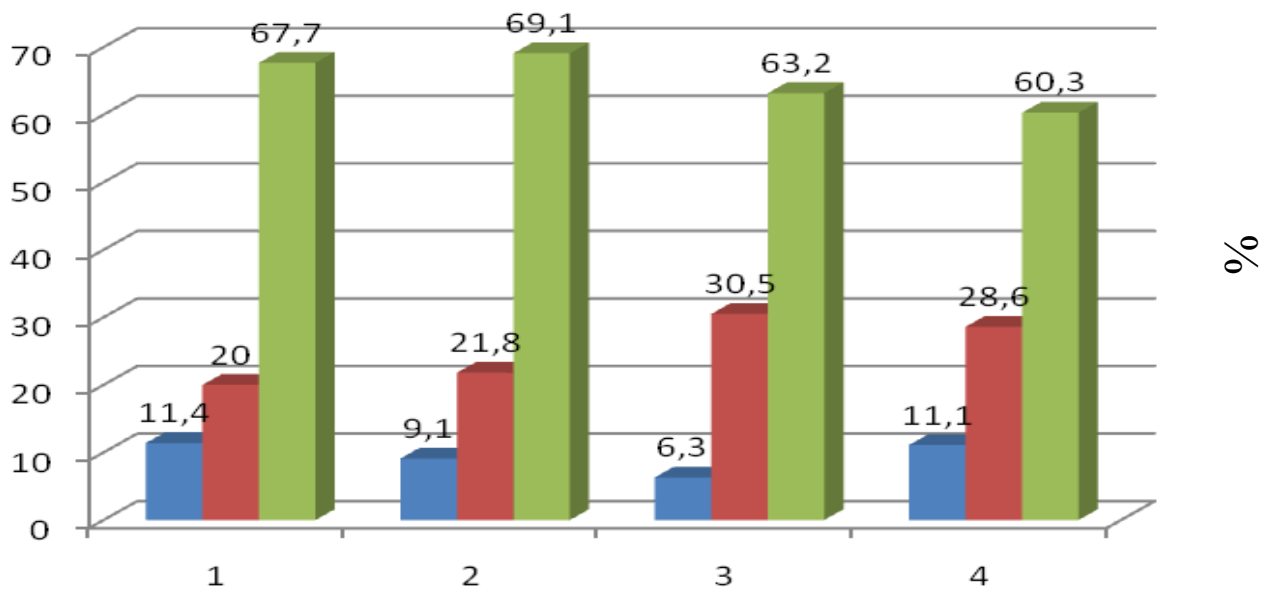

Fig. 3. Distribution of young men in grades 10-11 by health groups (GEC-General education classes, MBC-medical and biological classes)

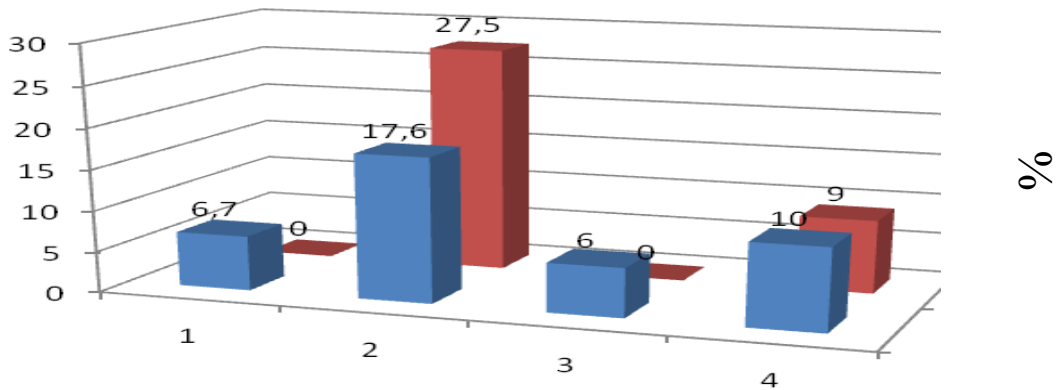

Fig. 4. Graphic representation of a light and expressive form of fatigue (\%) in boys of grades 10-11 of general education (GEC) and medical and biological classes (MBC)

In general, there is a tendency to reduce the number of students in the 11 th grade with the 3rd group of health and an increase in the content of the 2 nd group of health in comparison with the tenth graders.

The results obtained allowed us to establish that at the end of the 10th grade, primary and mild forms of chronic fatigue were determined in most cases in students of medical and biological profile, characterized by a slight decrease in performance, a decrease in interest in work, and sleep disorders (difficulty in waking up) (Fig. 4, Fig. 5). 


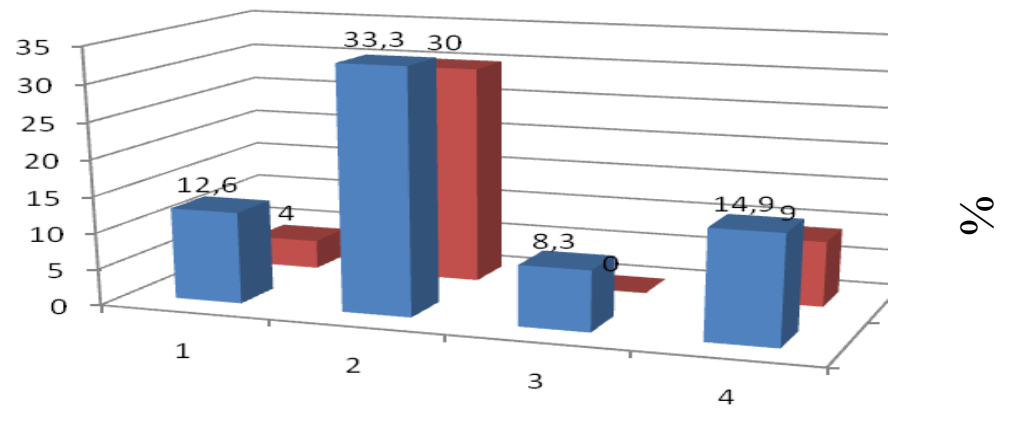

Fig. 5. Graphic representation of a light and expressive form of fatigue (\%) in girls of grades 10-11 of general education (GEC) and medico-biological classes (MBC)

By the end of the 11th grade, the number of students with the initial form of fatigue decreased and the number of boys and girls significantly increased in accordance with the light (from 6,7\% and $12,6 \%$ to $17,6 \%$ and $33,3 \%$ ) and severe (from $0 \%$ and $4 \%$ to $27,5 \%$ and $30,0 \%$ ) form of chronic fatigue. In comparison with students of medico-biological profile of students of secondary schools have similar dynamic changes of the psychophysiological state in the process of learning in high school, which was reflected in a decrease in the proportion of students with an initial degree of fatigue and the increase in the proportion of students in the light (in boys from $6 \%$ to $10 \%$, among girls - from $8,3 \%$ to $14,9 \%$ ), and expressed (in boys from 0 to $7,2 \%$; with 0 to $9.9 \%$ ) stages of fatigue. Apparently, these changes were expressed in high school students of General education classes much weaker. It should be noted that the general trend of changes in the psychophysiological state towards the proportion of students in a state of fatigue is equally characteristic of both boys and girls.

Of particular concern is the fact that by the end of the second year of study in biomedical classes significantly increased the number of students with severe form of fatigue which is characterized by a marked decline in health, fatigue at low loads, instability of mood and sleep disorders (difficulties falling asleep and Wake) (Fig. 6, Fig. 7).

According to the literature, students from secondary schools have respiratory diseases in the first ranking place; injuries, poisoning and some other consequences of external causes are in the second place; digestive diseases are in the third place; skin and subcutaneous tissue diseases are in the fourth place (Fig. 7). Our research has revealed slightly different data on the prevalence of school-related diseases in medical and biological classes. As evidenced by the results of the study (Fig. 6) diseases of the musculoskeletal system, visual analyzer and respiratory organs are in the first ranking places among high school students of medical and biological classes. 


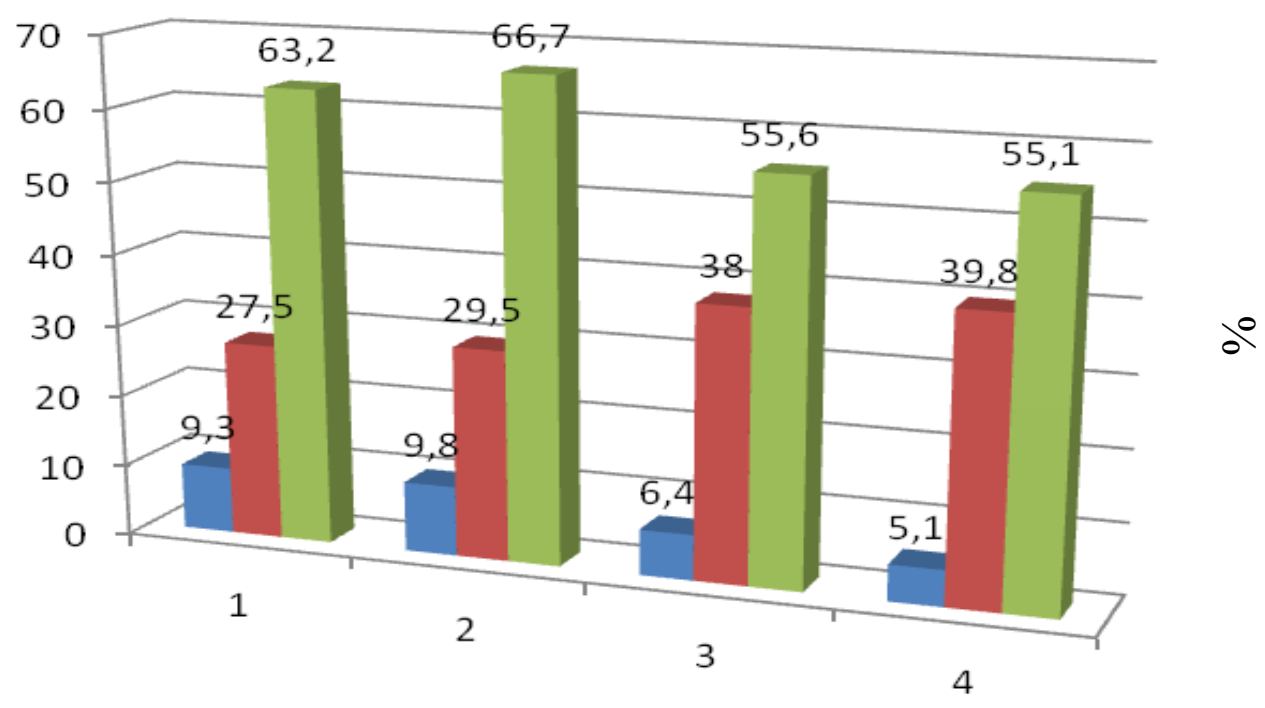

Fig. 6. Distribution of girls in grades 10-11 by health groups (GEC-general education classes, MBC-medical and biological classes).

Thus, the conducted psychophysiological research has demonstrated the presence of a significant proportion (in some schools, quite high) of students with pronounced degrees of chronic fatigue in comparison with students in general education classes.

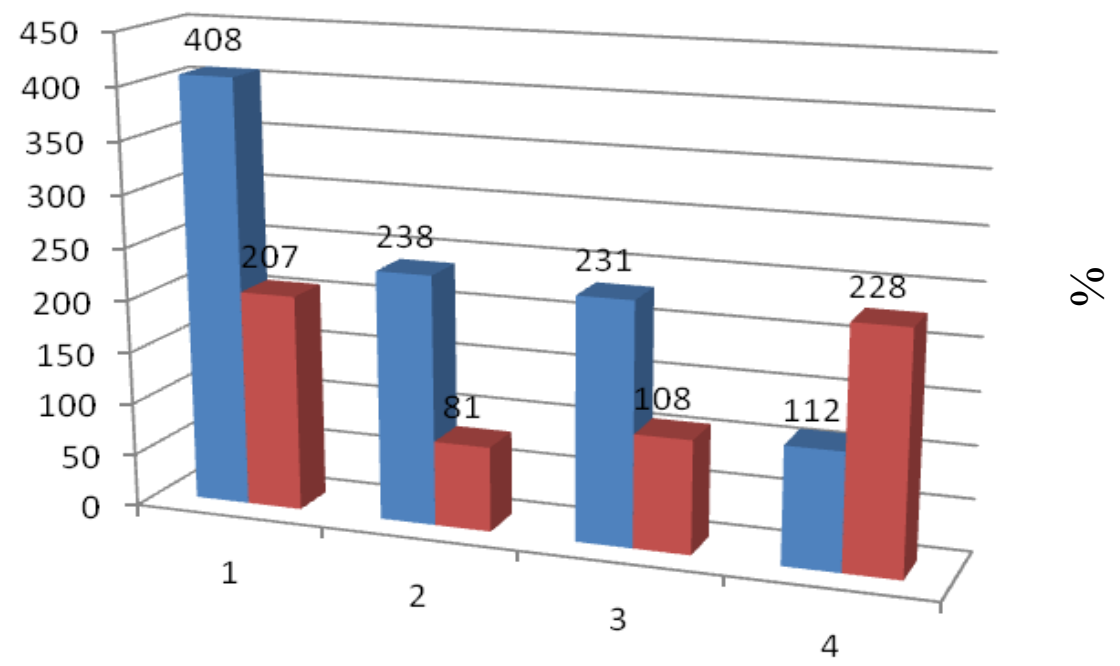

Fig. 7. Comparison of the spread of school-related diseases in medical and biological classes compared with General education classes (blue - data, red-literature)

Such data may be due to various reasons, but more likely and significant is the high academic load (exceeding the maximum allowable load, incorrect distribution of subjects during the day and week) both at school and outside 
(additional classes with Tutors, including during the holidays). So, almost a third of the students of the final classes of specialized classes had a state of pronounced fatigue, which can increase.

For a more detailed study of the functioning of the juvenile state we calculated the adaptive capacity of the cardiovascular system (CVS) before and after execution of methods of physical therapy, namely, therapeutic exercises, physical therapy, movement games (Fig. 8). Analysis of the results showed that the students level of adaptation of SSS is mostly average; below average is $13 \%$ above the average only $11 \%$. And after the experiment, the values of this indicator changed (Fig. 9). Below average adaptation of SSS is $10 \%$ of the surveyed students, the average is $59 \%$, above average $-21 \%$ had children $(10 \%)$, having a high level. This indicates that an increase in motor activity of adolescents leads to better functioning of the cardiological system.

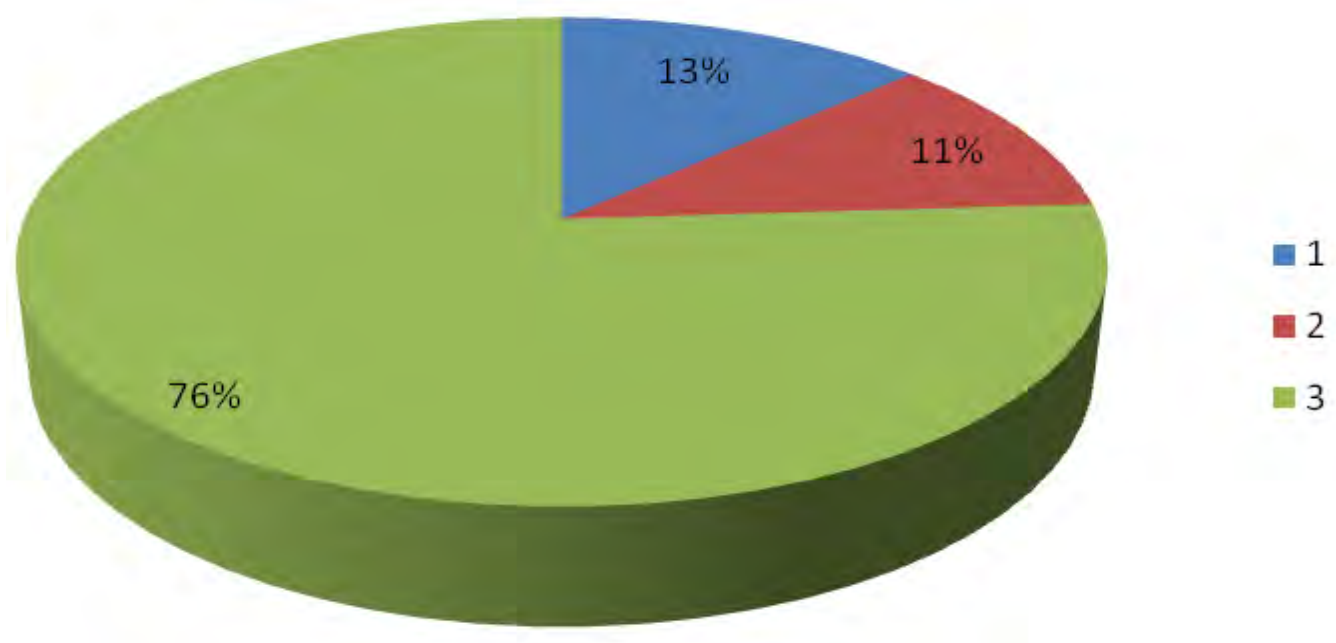

Fig. 8. Characteristics of the levels of cardiovascular system adaptation of adolescents to the experiment: 1-below average, 2 -above average, 3-average

We also determined the body mass index, vital capacity of the lungs (VEL), hand dynamometry, heart rate (HR) after 20 sit - UPS in 30 seconds, and based on these indicators, calculated the integral parameter-the level of physical health and adaptive capabilities to environmental conditions, and the value of this indicator before the experiment is presented in figure 10 .

The analysis of these data showed that the majority of pupils $(65 \%)$ have a satisfactory level of health, with disorders of adaptation mechanisms - the satisfactory condition, 25\% have a good level of health and adaptation, health status, good and moderate; $10 \%$ of children are characterized by poor level of health with insufficient adaptation, but healthy. After the experiment, the numerical values of this indicator changed (Fig. 11). 


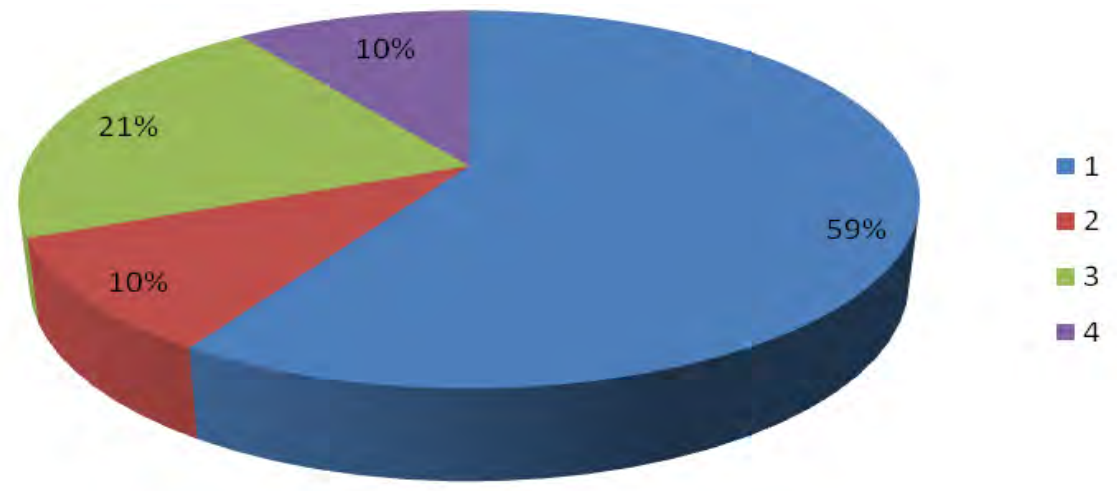

Fig. 9. Values of the levels of adaptive capabilities of the cardiovascular system after the experiment: 1-average, 2-below average, 3 -above average, 4 -high

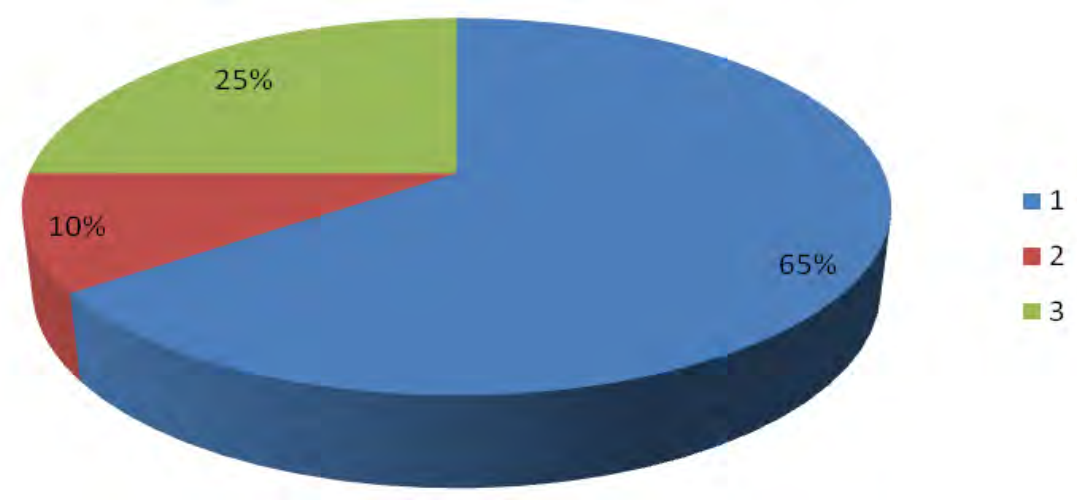

Fig. 10. Indicators of the level of physical health before the experiment: 1-satisfactory, 2-unsatisfactory, 3-good

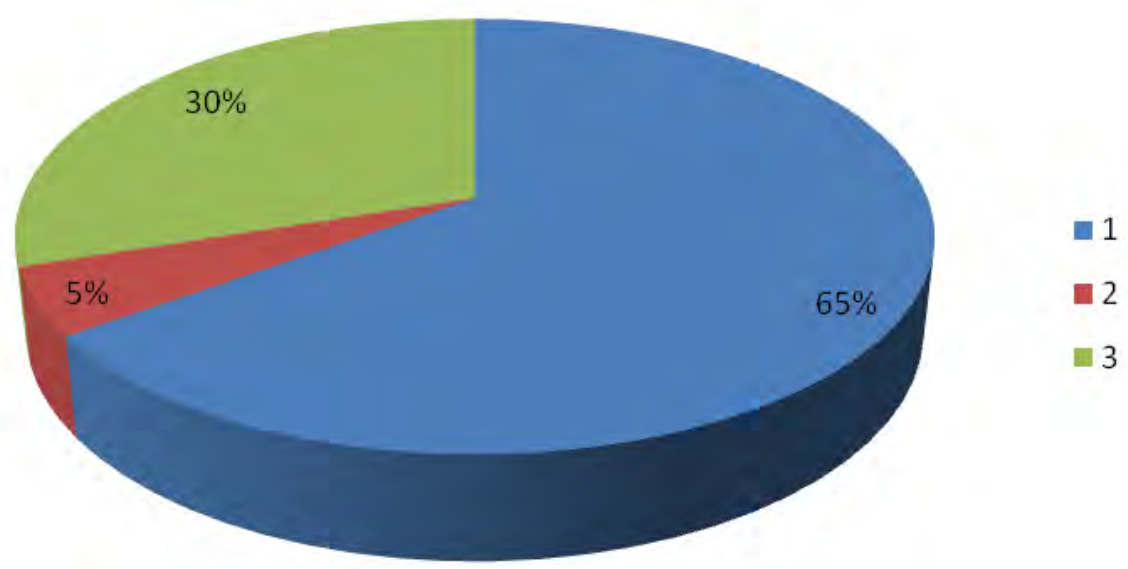

Fig. 11. Characteristic signs of the level of physical health of adolescents after the experiment: 1-satisfactory, 2-unsatisfactory, 3-good 
Regular physical exercise has a positive effect on the level of health of schoolchildren: children with a good level of health and adaptation increased by $5 \%$, as a result of which their condition became good and average, children with an unsatisfactory state of health and adaptation decreased by the same amount, because they moved to a satisfactory level, and therefore their state of health became satisfactory.

Physical development and health are strongly affected by bad habits, in particular Smoking, alcoholism, etc. The study of the prevalence of behavioral risk factors among students of medical and biological classes allowed us to obtain the following results. A third of girls (35,3\%) and almost half of boys $(46,3 \% ; p \leq 0,05)$ in specialized classes have already tried Smoking, but this is less than among students in general education classes. More than $50 \%(52,4-64,7 \%)$ of all school children showed no interest in Smoking and did not try it. In general, smoking as a harmful social attribute of society is not common in schools. The majority of high school students $(73,0-84,2 \%)$ do not smoke, along with $9,2 \%$ of girls and $10,5 \%$ of boys of medical and biological profile smoke daily. In general education classes, more students are constantly scorching, almost $10,3 \%$ of girls and $11,3 \%$ of boys.

As a result of an anonymous survey, it was revealed that $59,6 \%$ of girls with a medical and biological profile had tried alcoholic beverages, which is significantly lower in comparison with girls in General education classes. And among boys of the profile direction $61,7 \%$ of pupils tried alcoholic beverages, which is slightly lower in comparison with boys of General education classes. According to this, in general education classes, significantly fewer boys and girls did not try alcohol. A comparative assessment of the state of intoxication revealed no significant differences between medical and biological classes and general education classes. However, the data obtained indicate that the majority of schoolchildren $(72,8-74,1 \%)$ did not feel intoxicated at all. However, a group of girls $(20,6-21,3 \%)$ was identified who once felt this condition. Boys were intoxicated 2-3 times, which is significantly different from girls.

Analysis of the consumption of alcoholic beverages of various strengths found that beer is consumed monthly by both girls and boys, but the latter is significantly higher $(8,8$ and $9,8 \%$ against 24,7 and $20,5 \% ; p \leq 0,01, p \leq 0,05$, respectively). Sweet strong drinks (liquors) prefer to use a small percentage of girls of both types of classes. Strong alcoholic beverages are consumed monthly by $8,6 \%$ of boys in the profile direction and $10,8 \%$ of boys in general education classes; girls do not use vodka and cognac at all. In general, there is a tendency to increase the use of alcohol by schoolchildren in general education classes. The results of studying the lifestyle of students in grades 10-11 indicate differences in the organization of free time by students of medical and biological classes and general education classes. Thus, more 
students of medical and biological classes read books, attend elective classes, courses and clubs. Therefore, they get useful information from books, including textbooks, from teachers and parents. There are no noticeable differences in motor activity, computer use, and the spread of bad habits (smoking and alcohol addiction) among students of different types of education. Our research has reliably shown significant gender (sexual) differences in the lifestyle of high school students (girls and boys). Motor activity is significantly reduced in girls compared to boys - they often skip physical education classes and practically do not engage in clubs and sections. They work on the computer as well as boys, but prefer to read books, visit museums, exhibition halls and theaters. Bad habits, as shown by research, are not common among high school students in secondary schools. Most school children do not smoke, and girls and boys drink beer from alcoholic beverages. Sweet strong drinks in small quantities are usually preferred by girls, and boys - vodka and cognac.

\section{CONCLUSIONS}

Modern innovative teaching systems provide students with a full secondary education of increased complexity, which is characterized by the intensity of training and an increase in the volume of educational material, which increases the requirements for the body of students. Specialized training is becoming more and more developed, because it represents a promising innovation in education, in the implementation of which not only teachers are interested, but also the country as a whole.

The study of the features of the educational process in specialized and general education classes has shown that the high educational load and intensive nature of training in innovative schools is the main factor that affects the health of adolescents. The school schedule in grades 10-11 does not provide a rational distribution of lessons and does not correspond to the physiological curve of weekly performance of high school students. The schedule is usually represented by a two-humped curve, where the first maximum falls in the middle of the week, and the second-on the last days of the week (on Friday or Monday, or the training load is evenly distributed over all days of the week, which does not meet hygiene requirements).

Lifestyle analysis showed that the majority of teenagers do not smoke (73-84\%), but along with this, $9 \%$ of girls and $11 \%$ of boys in the medical and biological classes smoke every day. In general education classes, students who smoke accounted for $10-11 \%$. The data obtained showed that the majority of schoolchildren $-74-75 \%$ do not drink alcohol. But $20,5-21 \%$ of girls use alcohol periodically, and boys make up 30\% in both General education and medical and biological classes. In their free time, almost $40 \%$ of girls and $60 \%$ of boys watch TV and work at the computer. This means that 
not only in the educational process, but also in their free time, teenagers are dominated by statistical activities. Physical therapy methods that should be actively introduced into the school schedule of training sessions, in particular, therapeutic gymnastics, outdoor games, and therapeutic physical culture, help reduce the risk of hypodynamia and increase mental activity. This improves the body's non-specific immunity, restores the function of the Central nervous system, and promotes harmonious physical development. Physical activity is a universal adaptogen, that is, under its influence; there is a non-specific adaptation to various exo-and endogenous factors.

It is proved that the prevalence of disease, both in General and biomedical classes, are violations of the musculoskeletal device, cardiovascular system, respiratory system, vision system. The study of the integrative level of adaptive capabilities of the cardiovascular system has shown that under the influence of physical therapy methods has improved somewhat, namely: 59\% have an average level of adaptation, $21 \%$ - above average, $10 \%$ of children have risen to a high level. Regular physical exercise has a positive effect on the level of adolescent health: the number of children with a good level of health and adaptation has increased by $5 \%$, and the number of students with an unsatisfactory level has decreased by the same amount. It was found that the majority of students in grades 10-11 are constantly not getting enough sleep, because they sleep less than 6 hours: $35 \%$ of girls and $23 \%$ of boys; $7-8$ hours sleep $61 \%$ of girls and $63 \%$ of boys and only $4,0 \%$ of girls and $14 \%$ of boys sleep $8-9$ hours. It is shown that only $50-60 \%$ of teenagers eat Breakfast at home every day, $22 \%$ and $24 \%$ - at school. Most students' diets include fast food: $57 \%$ of girls consume 1-3 times a week and $40 \%$ of boysone or more per day. Such food violates the human immune system, increases the development of diabetes, cancer, etc. The experimental data obtained suggest that the proposed methods of physical therapy can be recommended for implementation in Ukrainian schools for high school students, both in General education and medical and biological classes.

\section{SUMMARY}

The article presents the medical and biological justification of multidisciplinary programs for physical therapy in the prevention of diseases of Ukrainian school-age children. It is shown that methods of physical therapy have a positive impact on the physical health and adaptive capabilities of students of medical and biological classes. Almost 59\% of children have reached an average level of adaptation, and $10 \%$ have reached a high level of physical health. The number of students with an unsatisfactory level of physical health and adaptation decreased by $5 \%$. The results of studying the lifestyle of students in grades 10-11 indicate differences in the organization of free time by students of medical and biological classes and General 
education classes. It is proved that the prevalence of disease, both in General and biomedical classes, are violations of the musculoskeletal device, cardiovascular system, respiratory system, vision system. Physical therapy methods used can be offered to school physical therapists to improve the health and adaptation of high schoolchildren.

\section{REFERENCES}

1. Галактионова М.Ю. Синдром вегетативной дисфункции у детей и подростков: вопросы диагностики, лечения, диспансеризации : методические рекомендации. Москва : МЕДпресс-информ, 2015. 48 с.

2. Гольдштейн Н.И., Гольдштейн Р.Н. Свежий воздух, супероксид и здоровье. Наука и жизнь. 2009. № 1. С. 94-99.

3. Григорьев К.И. Адаптация и стресс в детском возрасте. Москва : МЕДпресс-информ, 2014. 304 с.

4. Лильин Е.Т., Доскин В.А. Детская реабилитология. Москва : Литература, 2011.609 с.

5. Мухін В.М. Фізична реабілітація. Київ : Олімпійська література, 2005. $472 \mathrm{c}$.

6. Мухін В.М., Мальованій А.В., Мальована Г.П. Основи фізичної реабілітації. Львів, 2009. 120 с.

7. Barkmann C. Applicability and efficacy of variable light in school. Physiology \& Behavior. 2012. Vol. 105. P. 621-627.

8. Boreham C., Riddoch C. The physical activity, fitness and health of children. J. Sport Sci. 2011. Vol. 19. P. 915-929.

9. Grigg J. Air pollution and children's respiratory health - gaps in the global evidence. Clin Exp Allergy. 2011. Vol. 41 (8). P. 1072-1075.

\section{Information about authors: \\ Pyurko V. E.,}

Master in Physical Therapy and Occupational Therapy, Physical Therapy Teacher, Teacher's Assistant Melitopol Secondary School of I-III stages № 22 of the Melitopol city Council of Zaporozhye region 32, 2 provulok Liutnevyi str., Melitopol, Zaporizhzhya region, 72304, Ukraine

Kazakova S. M., Candidate of Biological Sciences, Associate Professor at the Department of Physical Rehabilitation

Melitopol Institute of Ecology and Social Technologies of the Open International University of Human Development "Ukraine" 380, Interkulturna str., Melitopol, Zaporizhzhya region, 72316, Ukraine 